\title{
Newer Dolerite dykes, Jharkhand, India: a case study of magma generation, differentiation and metasomatism in a subduction zone setting
}

\author{
PIYALI SENGUPTA* and ARIJIT RAY \\ Department of Geology, Presidency University, 86/1 College Street, Kolkata-700073, West Bengal, India
}

(Received November 18, 2011; Accepted August 10, 2012)

\begin{abstract}
The NE-SW, NW-SE and E-W trending Proterozoic Newer Dolerite dykes around Chaibasa, Jharkhand, India are found to intrude Singhbhum Granites of late Archean age. Clouded plagioclase, bastitised orthopyroxene and uralitized clinopyroxene, magnetite-ilmenite, quartz-feldspar granophyric intergrowth are the characteristic minerals present in the dolerite dykes which assign a low grade metamorphosed character to the dolerite. Both olivine normative and quartz normative varieties are observed in this suite of dykes. These dolerites have been classified into two groups on the basis of REE distribution patterns: one with LREE (Light Rare Earth Element) enriched pattern (Group I) and the other with flat REE pattern (Group II). A significant positive correlation among trace elements $\mathrm{Nb}, \mathrm{Zr}$, La, Ce for Group I dykes suggest variable degree of partial melting of the mantle source. In tectonic discrimination diagrams made with immobile incompatible trace elements $\mathrm{Nb}, \mathrm{Zr}$, Ti and Y, Group I dykes show arc-like geochemical signature while Group II dykes are similar to MORBs. Enrichment in some of the LILE and prominent depletion in Nb, P and Ti in Group I dykes suggest that the original melt was derived from a metasomatised mantle source. Group II dykes might derived from a MORB-type mantle source. Melting was triggered by volatiles in case of dykes of Group I while for the Group II dykes, melting was produced by thinning of the lithosphere and subsequent decompression.
\end{abstract}

Keywords: Newer Dolerite, subduction, clouded plagioclase, decompression, mantle

\section{INTRODUCTION}

Mafic dyke swarms provide the most complete record of short-lived, mantle-generated magmatic events through time and space (Bleeker, 2004; Ernst and Buchan, 2001). The Indian shield areas exhibit numerous mafic dykes of Proterozoic age in Bundelkhand, Bastar, Dharwar and Singhbhum Orissa cratons of India (Mondal and Ahmad, 2001; Subba Rao et al., 2004; Srivastava, 2006; Murthy, 1995; Radhakrishna et al., 2007). In Singhbhum region, a spectacular set of reticulating basic dyke swarm, the Newer Dolerite suite, traverses the Precambrian Singhbhum granitic complex (Dunn, 1929; Jones, 1934; Krishnan, 1936; Dunn and Dey, 1942; Saha, 1948, 1952, 1994; Saha et al., 1972, 1973; Mahadevan, 2002) over a wide period from 2100 to $950 \mathrm{Ma}$ (Sarkar and Saha, 1977; Mallick and Sarkar, 1994). There is no detailed geochemical study of these dykes swarms which might provide some indication on time and space evolution of the mantle sources beneath these important Indian cratons of Archean age. According to earlier workers, Newer Dolerites with variable $\mathrm{Mg}$ number and iron enrichment

*Corresponding author (e-mail: piysen@yahoo.co.in)

Copyright (c) 2012 by The Geochemical Society of Japan. belong to different generations (Saha et al., 1973). The geochemical characters of these dykes are strikingly uniform over a long period of time (Bose, 2008; Mallick and Sarkar, 1994). Bose (2008) suggested that Newer Dolerite dykes generated through partial melting of subcontinental mantle which in turn was metasomatised. Mir et al. (2010) documented geochemical characteristics of these dykes similar to those of back arc extension basalts (BABB). In the studied area shear fractures which appears to act as pathways of these mafic intrusives have two dominant trends NE-SW and E-W and a subsidiary NW-SE trends. This might suggest that stress system have not an uniform direction over a long period, but it changed orientation with time. The geochemical classification of these dykes and their linking to possible tectonic settings have not yet been reported by earlier workers. In the present work, attempts have been made to classify these dykes according to their trace and REE composition. The genesis of different chemical types of Newer Dolerite dykes has been discussed in the perspective of possible tectonic setting.

\section{Geological Setting}

There is a prevalent idea to consider the Singhbhum craton as a "greenstone granite terrain" (Mahadevan, 


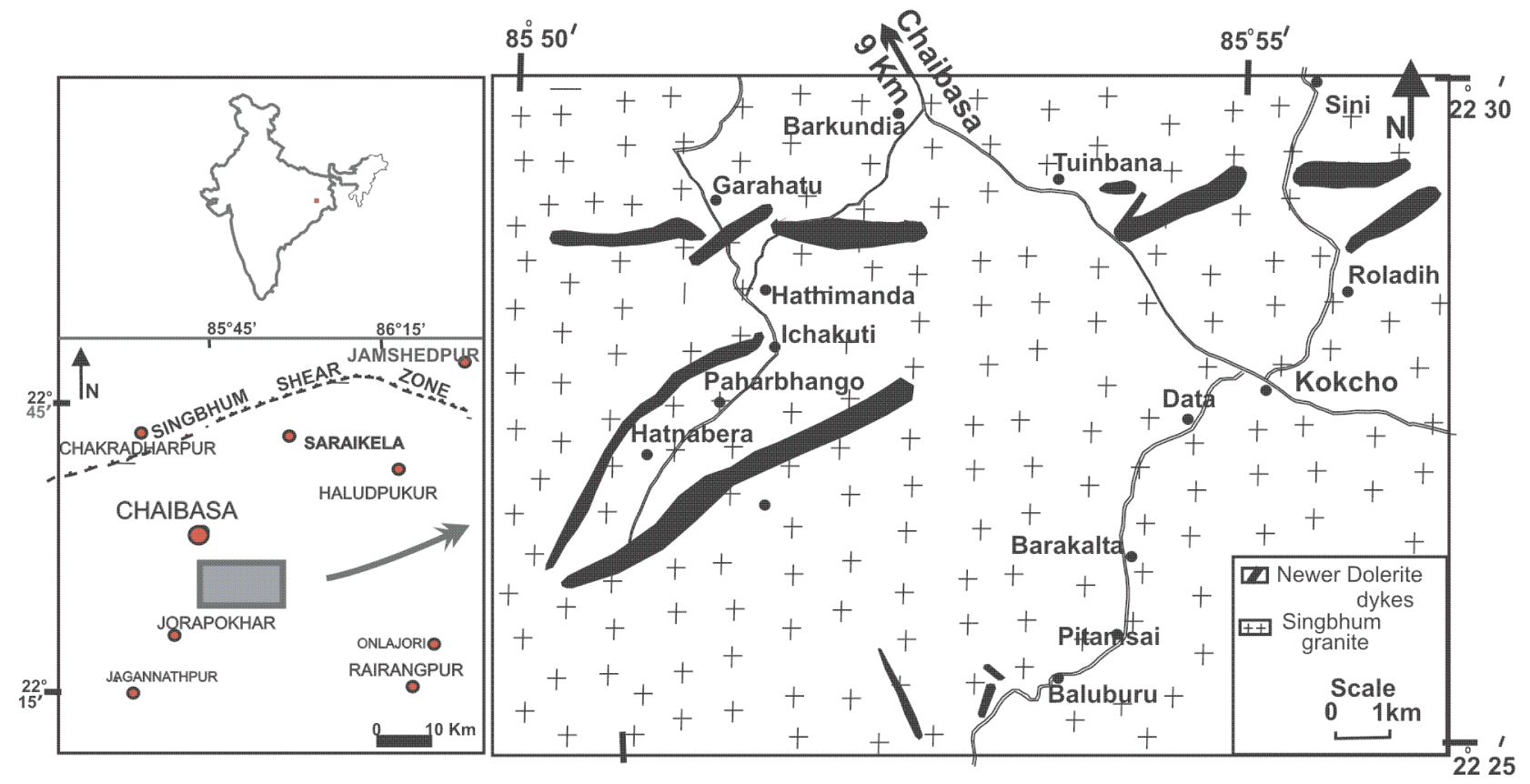

Fig. 1. Geological map of the studied area, south of the Singhbhum Shear Zone. Solid block indicates the study area which has been blown up to show occurrences of Newer Dolerite Dykes of Chaibasa within Singhbhum Granite. Important towns and villages around the study area have also been marked.

2002) because of sedimentary and tectonic characteristics similar to those found in greenstone belts. Along the western and eastern margins of the Singhbhum platformal nucleus, extensive volcano-sedimentary sequences containing banded iron formations occur. Sporadic high magnesian lavas having affinity with picrite, komatiite and boninite have been reported (Sengupta et al., 1997; Bose 1982, 2000; Sahu and Mukherjee, 2001; Mandal et al., 2006). All these discrete volcano-sedimentary basins, developed peripheral to the Singhbhum granite pluton, represent sequential development of greenstone belts in changing tectonic environments (Thurston, 1990) from platformal margin to destructive plate tectonic margin (Bose, 2000).

Singhbhum group in East Singhbhum show four phases of folding, $\mathrm{F}_{1}, \mathrm{~F}_{2}, \mathrm{~F}_{3}$ and $\mathrm{F}_{4}$ related to compression in an arc setting (Bhattacharyya and Sanyal, 1988; Saha, 1994). Sedimentary facies variations indicate that the Chaibasa formation is a flysch (Saha, 1994; Mahadevan, 2002; Mukhopadhyay, 1988; Sinha-Roy and Gupta, 1995). In the northern fringe of the Singhbhum nucleus there is a Proterozoic Singhbhum basin (PSB) which shows characteristic bimodal volcanic geochemistry (shown in the mid-basinal Dalma volcanic belt) and related tectono-sedimentary features of Archean greenstone belts (Bose and Chakraborty, 1992; Bose et al., 1989; Condie, 1990; Bose, 2000). Reconstruction of the paleo-tectonic setting (Chakraborty and Bose, 1985) suggests that PSB is a rifted continental margin generated in an extensional tectonic regime (Bose, 1994). The PSB sediments testify dual (granitic basement and basic volcanic) provenances in the mixed lithological package (Bose, 1994) usually observed in many Proterozoic marginal basins formed in a back-arc setting (Smith, 1992). According to (Condie, 2001), komatiites and MORBs possibly represent a Neoproterozoic plume-fed slab captured into an arc, as also suggested by the presence of boninites in the Dalma volcanic rocks (Naqvi, 2005). All these features indicate that the Singhbhum mobile belt was accreted to the Singhbhum nucleus. This type of accretion is common in accretionary sedimentary prisms of volcanic arc.

Newer Dolerite dykes intruding the Singbhum Granite have ages from Paleoproterozoic to Neoproterozoic (2100-900 Ma). The studied area is located south of Chaibasa (Fig. 1), in the state of Jharkhand, India. The Newer dolerite dykes outcrop as long serrated ridges, as linearly arranged hills and as stony wastes showing a NESW and NW-SE trend within the Singhbhum Granite (Fig. 1). A few E-W trending dykes occur both as long ridges and also as stony wastes. Being a part of the granite greenstone belt of Singbhum craton, these dykes show petrologic and geochemical signatures suggesting an intrusion in an arc-back arc setting. 
Table 1. Representative EPMA data of pyroxene grains in Newer Dolerite dykes of Chaibasa

\begin{tabular}{|c|c|c|c|c|c|c|c|c|}
\hline $\begin{array}{l}\text { Analysis No. } \\
\text { Description }\end{array}$ & $\begin{array}{l}\text { 43/P3 } \\
\text { Cpx }\end{array}$ & $\begin{array}{l}\text { 6/6* } \\
\text { Cpx }\end{array}$ & $\begin{array}{c}113 / \mathrm{P} 9 \\
\mathrm{Cpx}\end{array}$ & $\begin{array}{l}\text { 9/6* } \\
\text { Cpx }\end{array}$ & $\begin{array}{l}35 / \mathrm{P} 8 \\
\mathrm{Cpx}\end{array}$ & $\begin{array}{c}48 / \mathrm{P} 3 \\
\mathrm{Cpx}\end{array}$ & $\begin{array}{l}6 / 6^{*} \\
\text { Opx }\end{array}$ & $\begin{array}{c}110 / \mathrm{P} 9 \\
\mathrm{Opx}\end{array}$ \\
\hline $\mathrm{SiO}_{2}$ & 51.23 & 51.54 & 50.28 & 52.17 & 51.84 & 50.51 & 51.54 & 55.81 \\
\hline $\mathrm{TiO}_{2}$ & 0.34 & 0.61 & 0.65 & 0.24 & 0.38 & 0.87 & 0.61 & 0.15 \\
\hline $\mathrm{Al}_{2} \mathrm{O}_{3}$ & 2.56 & 0.65 & 1.96 & 1.54 & 1.85 & 1.89 & 0.65 & 0.96 \\
\hline $\mathrm{FeO}$ & 6.64 & 26.5 & 13.73 & 18.42 & 9.89 & 13.87 & 26.5 & 9.45 \\
\hline $\mathrm{Cr}_{2} \mathrm{O}_{3}$ & 0.77 & 0 & 0.06 & 0.1 & 0.01 & 0.15 & 0 & 0.47 \\
\hline $\mathrm{MnO}$ & 0.22 & 0.44 & 0.16 & 0.28 & 0.28 & 0.29 & 0.44 & 0.19 \\
\hline $\mathrm{MgO}$ & 15.82 & 19.05 & 13.94 & 18.42 & 16.25 & 14.67 & 19.05 & 30.62 \\
\hline $\mathrm{CaO}$ & 22.07 & 2.01 & 18.39 & 9.5 & 18.3 & 17.75 & 2.01 & 1.84 \\
\hline $\mathrm{Na}_{2} \mathrm{O}$ & 0.3 & 0.08 & 0.25 & 0.08 & 0.22 & 0.29 & 0.08 & 0.05 \\
\hline $\mathrm{K}_{2} \mathrm{O}$ & 0.02 & 0.01 & 0.02 & 0 & 0.02 & 0 & 0.01 & 0 \\
\hline Total & 99.97 & 100.89 & 99.44 & 100.75 & 99.04 & 100.29 & 100.89 & 99.54 \\
\hline \multicolumn{9}{|c|}{ Number of ions on the basis of 6 oxygen } \\
\hline $\mathrm{Si}$ & 1.885 & 1.945 & 1.902 & 1.938 & 1.936 & 1.892 & 1.972 & 1.945 \\
\hline $\mathrm{Al}$ & 0.111 & 0.029 & 0.087 & 0.067 & 0.081 & 0.083 & 0.03 & 0.029 \\
\hline $\mathrm{Fe}^{3+}$ & 0.099 & 0.054 & 0.089 & 0.046 & 0.042 & 0.076 & 0 & 0.027 \\
\hline $\mathrm{Ti}$ & 0.009 & 0.017 & 0.018 & 0.007 & 0.011 & 0.025 & 0.004 & 0.017 \\
\hline $\mathrm{Fe}^{2+}$ & 0.106 & 0.782 & 0.345 & 0.526 & 0.267 & 0.333 & 0.279 & 0.782 \\
\hline $\mathrm{Cr}$ & 0.022 & 0 & 0.002 & 0.003 & 0 & 0.004 & 0.013 & 0 \\
\hline $\mathrm{Mg}$ & 0.868 & 1.072 & 0.786 & 1.02 & 0.905 & 0.819 & 1.513 & 1.072 \\
\hline $\mathrm{Mn}$ & 0.007 & 0.014 & 0.005 & 0.009 & 0.009 & 0.009 & 0.006 & 0.014 \\
\hline $\mathrm{Ca}$ & 0.87 & 0.081 & 0.745 & 0.378 & 0.732 & 0.712 & 0.07 & 0.081 \\
\hline $\mathrm{Na}$ & 0.021 & 0.006 & 0.018 & 0.006 & 0.016 & 0.021 & 0.003 & 0.006 \\
\hline $\mathrm{K}$ & 0.001 & 0 & 0.001 & 0 & 0.001 & 0 & 0 & 0 \\
\hline Wo & 44.64 & 4.06 & 37.82 & 19.10 & 37.46 & 36.07 & 3.54 & 4.06 \\
\hline En & 44.52 & 53.50 & 39.89 & 51.54 & 46.28 & 41.47 & 81.98 & 53.50 \\
\hline Fs & 10.84 & 42.44 & 22.30 & 29.36 & 16.26 & 22.46 & 14.48 & 42.44 \\
\hline
\end{tabular}

\section{RESULTS AND DISCUSSION}

\section{Petrology}

The studied dykes are greenish black to greyish black in color and occur both as fine-grained porphyritic and coarse-grained non-porphyritic varieties. Some huge dykes show fine-grained varieties close to the granite contact gradually becoming coarser away. Thin-section observations reveal that the rocks are essentially composed of clinopyroxene and plagioclase either as phenocryst in porphyritic variety or form an assemblage showing intergranular texture. Clinopyroxene occurs as single prismatic grains and as clusters. Compositionally, clinopyroxene shows a wide range of compositional variation from $\mathrm{Wo}_{44.6} \mathrm{En}_{44.6} \mathrm{Fs}_{10.8}$ to $\mathrm{Wo}_{4.1} \mathrm{En}_{53.5} \mathrm{Fs}_{42.4}$ (Table 1) from augite, subcalcic augite, ferroaugite to pigeonite. Some large clinopyroxene grains show conspicuous zoning. In some dykes, clinopyroxene is variably replaced by chlorite, tremolite and actinolitic amphibole. Minor amounts of actinolite discrete grains have also been observed in few cases. Orthopyroxene, partly altered to bastite (Fig. 2a) occurs as a major mineral $\left(\mathrm{Wo}_{3.54} \mathrm{En}_{81.98} \mathrm{Fs}_{14.48}\right.$, Table 1) in some dykes and it is sometimes associated with anorthitic plagioclase
$\left(\mathrm{An}_{86.7}\right)$ (Table 2). In the studied dolerite dykes, the orthopyroxene appears to be not a magmatic phase but a reaction product from clinopyroxene. Textural study indicates that such transformation as orthopyroxene is always found adjacent to clinopyroxene and is associated with $\mathrm{Ca}$-plagioclase. It is likely that orthopyroxene grains might have formed by contamination of granitic country rock by the parent magma according to the following reaction (Deer et al., 1997):

\section{Ca-rich pyroxene + assimilation of Al-rich rock}

$\rightarrow$ Orthopyroxene + Ca-rich plagioclase.

Fresh plagioclase grains are very rare in the studied dolerites. They are mostly clouded showing dark- to lightcolored patchy appearance (Fig. 2b). Wide variations in composition (from $\mathrm{An}_{86.7}$ to $\mathrm{An}_{13.3}$ ) are observed in different parts of a single unzoned clouded plagioclase grain (Table 2). Clouding in feldspar occurs widely in mafic dykes that transect Proterozoic shield areas such as satellite dykes of the Great Dyke in Zimbabwe (Robertson and Van Breemen, 1970), Matachewan dykes of the Canadian shield (Halls et al., 1994), dykes on Wyoming shield, USA (Armbrustmacher and Banks, 1974) and in Dharwar 

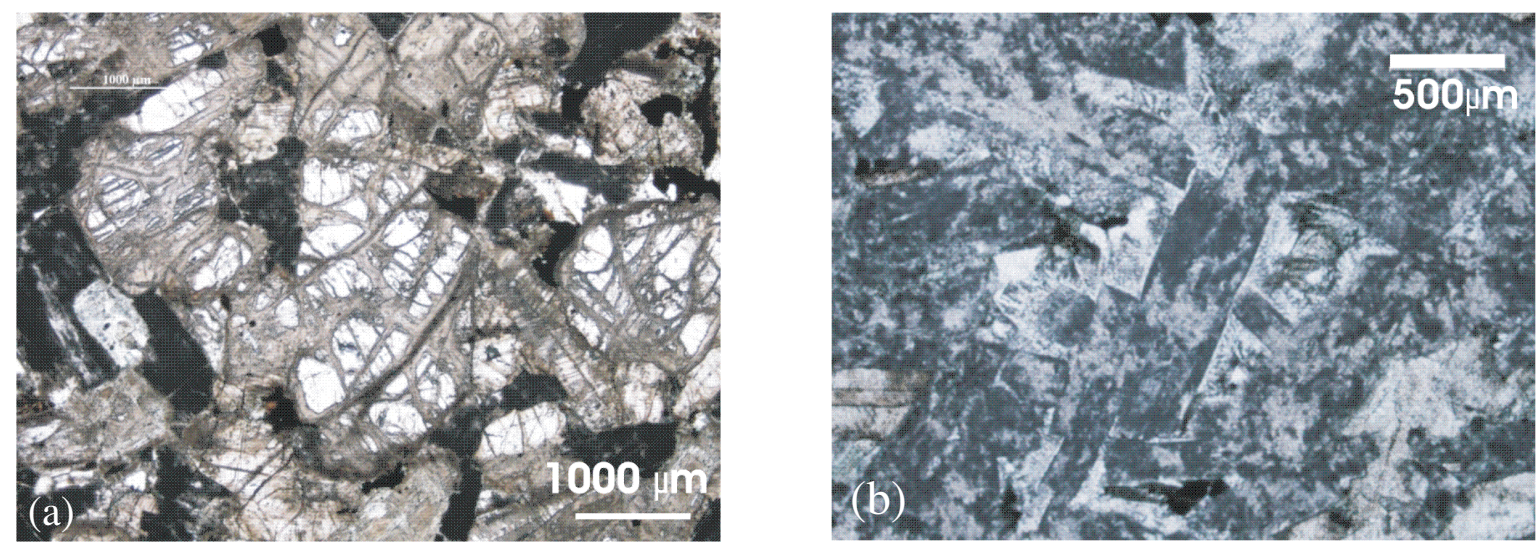

Fig. 2. (A) Photomicrograph of bastitised orthopyroxene in plane polarized light. (B) Photomicrograph of plagioclase feldspar grains showing clouding in plane polarized light.

Table 2. Representative EPMA data of plagioclase grains in Newer Dolerite Dykes of Chaibasa

\begin{tabular}{lcccccc}
\hline $\begin{array}{l}\text { No. } \\
\text { Description }\end{array}$ & $\begin{array}{c}11 / 6^{*} \\
\text { clouded plag }\end{array}$ & $\begin{array}{c}19 / 6^{*} \\
\text { clouded plag }\end{array}$ & $\begin{array}{c}82 / \mathrm{P} 10 \\
\text { clouded plag }\end{array}$ & $\begin{array}{c}27 / 8 \\
\text { plag core }\end{array}$ & $\begin{array}{c}47 / 11 \\
\text { plag }\end{array}$ & $\begin{array}{c}98 / 12 \\
\text { plag }\end{array}$ \\
\hline $\mathrm{SiO}_{2}$ & 43.06 & 40.93 & 45.82 & 65.93 & 67.56 & 54.68 \\
$\mathrm{TiO}_{2}$ & 0.04 & 0.06 & 0 & 0.03 & 0 & 0.1 \\
$\mathrm{Al}_{2} \mathrm{O}_{3}$ & 30.08 & 28.15 & 25.98 & 20.28 & 19.43 & 26.66 \\
$\mathrm{FeO}$ & 1.36 & 4.97 & 4.77 & 0.04 & 0.14 & 0.83 \\
$\mathrm{MnO}$ & 0 & 0.11 & 0.07 & 0 & 0 & 0 \\
$\mathrm{MgO}$ & 0.03 & 0 & 0.02 & 0 & 0.03 & 0.05 \\
$\mathrm{CaO}$ & 21.24 & 23.36 & 21.24 & 1.56 & 0.5 & 10.78 \\
$\mathrm{Na}{ }_{2} \mathrm{O}$ & 1.8 & 0.96 & 0.59 & 10.72 & 11.21 & 5.22 \\
$\mathrm{~K}_{2} \mathrm{O}$ & 0.01 & 0 & 0.01 & 0.09 & 0.04 & 0.44 \\
$\mathrm{Total}$ & 97.62 & 98.54 & 98.5 & 98.65 & 98.91 & 98.76 \\
$\mathrm{Cations}$ on the basis & & & & & & \\
$\mathrm{Si}$ & oxygens & & & & & \\
$\mathrm{Al}$ & 4.389 & 4.42 & 4.797 & 5.873 & 5.976 & 5.082 \\
$\mathrm{Ti}$ & 3.611 & 3.58 & 3.203 & 2.127 & 2.024 & 2.918 \\
$\mathrm{Fe}$ & $2+$ & 0 & 0.004 & 0 & 0.001 & 0.005 \\
$\mathrm{Mg}$ & 0.003 & 0.036 & 0.037 & 0.001 & 0.082 & 0.449 \\
$\mathrm{Ca}$ & 0.116 & 0 & 0.004 & 0 & 0.012 & 0 \\
$\mathrm{Na}$ & 0.005 & 0.263 & 0.493 & 0.006 & 0.844 & 2.703 \\
$\mathrm{~K}$ & 2.32 & 1.613 & 1.418 & 1.981 & 1.142 & 0.201 \\
$\mathrm{Ab}$ & 0.356 & 0.108 & 0.114 & 0.007 & 0.036 & 0 \\
$\mathrm{An}$ & 0.001 & & & & & \\
$\mathrm{Or}$ & 13.3 & 81.3 & 62.3 & 99.3 & 56.5 & 6.9 \\
\hline & 86.7 & 13.3 & 25.3 & 0.3 & 41.7 & 93.1 \\
& 0 & 5.4 & 12.4 & 0.4 & 1.8 & 0 \\
\hline & & & & & &
\end{tabular}

craton, India (Pichamuthu, 1959). The cloudiness is not an original feature of feldspars. It is a product of thermal metamorphism caused either by regional heating connected with depth or by the heat of neighboring igneous magma (MacGregor, 1931). Because there is no evidence for nearby intrusive rocks of later origin, we can consider the low-grade metamorphism as the possible cause for feldspar clouding in our area. Some plagioclases also show alteration like saussuritization (process by which calcium-bearing plagioclase feldspar is altered to a char- acteristic assemblage of minerals called saussurite) and sericitization. Unclouded small relict grains of plagioclase are extremely rare showing mostly albitic $\left(\mathrm{Ab}_{99.6}\right.$ to $\left.\mathrm{Ab}_{56.5}\right)$ compositions. The common accessory mineral in the rock is magnetite, associated occasionally with ilmenite. Few biotite and sphene also occur as accessories. Interstitial quartz and micropegmatite are also commonly developed and often constitute significant proportion of the rock. Presence of actinolitic amphibole, bastitised orthopyroxene and clouded plagioclase suggest 


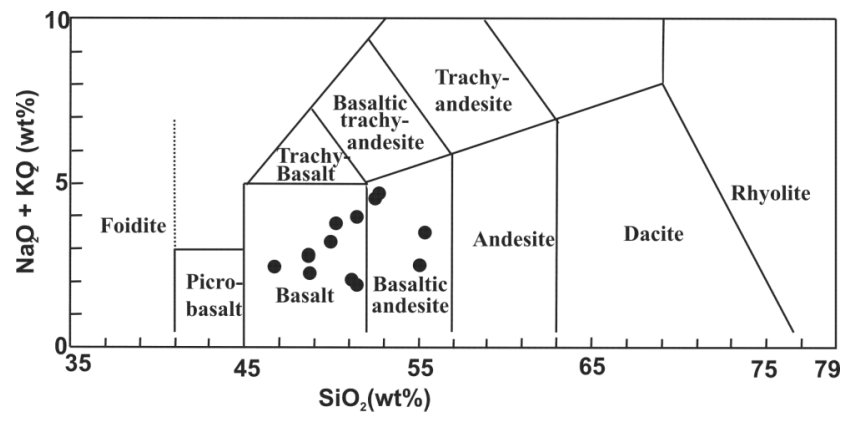

Fig. 3. Total alkali silica (TAS) diagram (after Le Maitre, 2002). Newer Dolerite dykes plot in the field of basalt and basaltic andesite.

regional metamorphism under greenschist facies conditions.

\section{Geochemistry}

Twelve samples have been selected for whole rock major oxide analyses and thirteen samples for trace element analyses (Table 3). Major oxide analyses were carried out by XRF at the Wadia Institute of Himalayan Geology, Dehradun, India. Trace elements including rare earth elements were analyzed with a Perkin Elmer, Sciex ELAN DRC II ICP-MS at the National Geophysical Research Institute, Hyderabad, India. International rock standards BHVO-1, BR (major elements) and JB2 (trace and REE) were run along with the samples to determine the precision and accuracy. The analyzed and certified values of BHVO-1 and JB2 are given in Table 3. Composition of constituent minerals were determined by Electron Probe Micro Analyses (EPMA) in the laboratory of Geological Survey of India, Kolkata using a CAMECA SX-100 with $15 \mathrm{kV}$ voltage, $12 \mathrm{nA}$ current and a beam size of 1 micron.

The dolerites have basalt to basaltic andesite compositions (Fig. 3). Major oxides show a wide range of compositional variation as shown in Table 3. The wide range of variation in $\mathrm{SiO}_{2}$ content, $\mathrm{Mg}$-numbers (here calculated as $\left.\left[\mathrm{Mg}^{2+} /\left(\mathrm{Mg}^{2+}+\mathrm{Fe}_{\text {tot }}\right)\right]\right)$ and $\mathrm{TiO}_{2}$ content possibly indicates the occurrence of more than one chemical type of mafic dykes in the Newer Dolerite suite. The samples show a prominent iron-enrichment trend in the AFM diagram (Fig. 4) indicating their tholeiitic nature. Few dykes also show a calc-alkaline nature. The $\mathrm{Mg}$ numbers vary from 0.39 to 0.65 indicating the presence of primitive to highly differentiated rocks in the Newer Dolerite suite. The dykes with low Mg-numbers are likely to be a crystallization product of an evolved magma or might have generated from a relatively iron-rich mantle source. Such iron enrichment is usually the result of mantle metasomatism processes as reported by Hoal (2003), Hanski and Smolkin (1995) and Kelemen (1990). Among

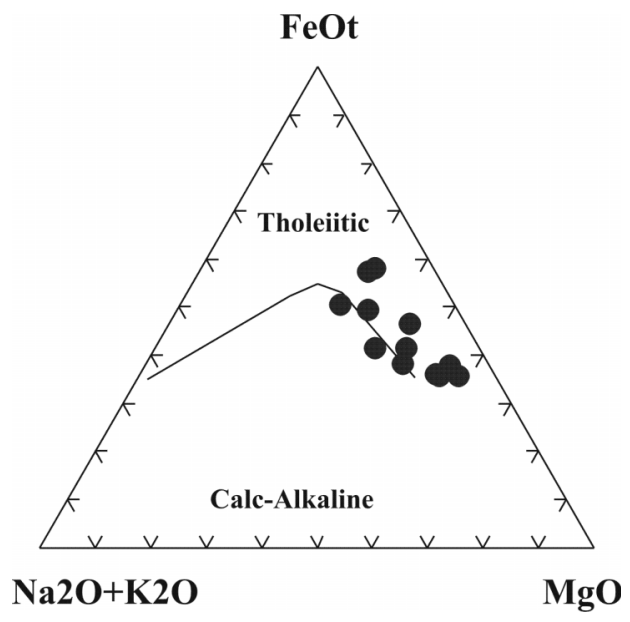

Fig. 4. Plots of the Newer Dolerite dykes in the AFM diagram (Irvin and Baragar, 1971).

the twelve samples, eight samples are silicaundersaturated and olivine-normative (maximum value of 14.77) while the others are quartz-normative (maximum value of 3.87) as shown in Table 1.

Major element, trace element and REE geochemistry of the Newer Dolerite

When plotted in a chondrite-normalized diagram (Fig. 5), the thirteen dolerite samples of the Newer Dolerite suite fall into two distinct groups: nine dykes in Group I (P1, P2, P3, P4, P5, P6A, P7, P8, P9 and P12) and three others in Group II (P6, P10, P11). The Group-I dykes show a REE abundance $~ 100$ times higher than the chondritic composition with a sharply fractionated LREE enrichment pattern and $(\mathrm{La} / \mathrm{Sm})_{\mathrm{N}}$ ratios vary from 2.6 to 3.7. The REE pattern of Group-II dykes is nearly flat with a slight enrichment in LREEs. For Group-II, the $(\mathrm{La} / \mathrm{Sm})_{\mathrm{N}}$ ratio varies from 1.11 to 1.26 which is typical of E-MORB (Sun and McDonough, 1989). MORB normalized LILE-HFSE pattern (Fig. 6A) depicts the distinct characters of GroupI and Group-II dykes. Both groups of dykes show positive anomalies of $\mathrm{K}$ and $\mathrm{Rb}$ and negative anomalies of $\mathrm{Ba}, \mathrm{Nb}, \mathrm{Ta}, \mathrm{Zr}$ and $\mathrm{Hf}$ with respect to the MORB and the chondrite compositions. The differences in the selected trace element compositions of Group-I and Group-II dykes are revealed by the nature of anomalies of Th, $\mathrm{P}$ and Ti. Group-I dykes show a positive anomaly of Th and a negative anomaly of $\mathrm{P}$ and $\mathrm{Ti}$ compared to MORB whereas the Group-II dykes do not show these are devoid of these anomalies. Similar features are also observed in the chondrite-normalized trace element diagram (Fig. 6B).

The REE multi-element diagrams (Figs. 5, 6A, 6B) of Group-I dykes show LREE and LILE enrichment and high field strength elements (HFSE) depletion ( $\mathrm{Nb}, \mathrm{P}$ and $\mathrm{Ti}$ anomalies) compared to the chondritic and MORB com- 


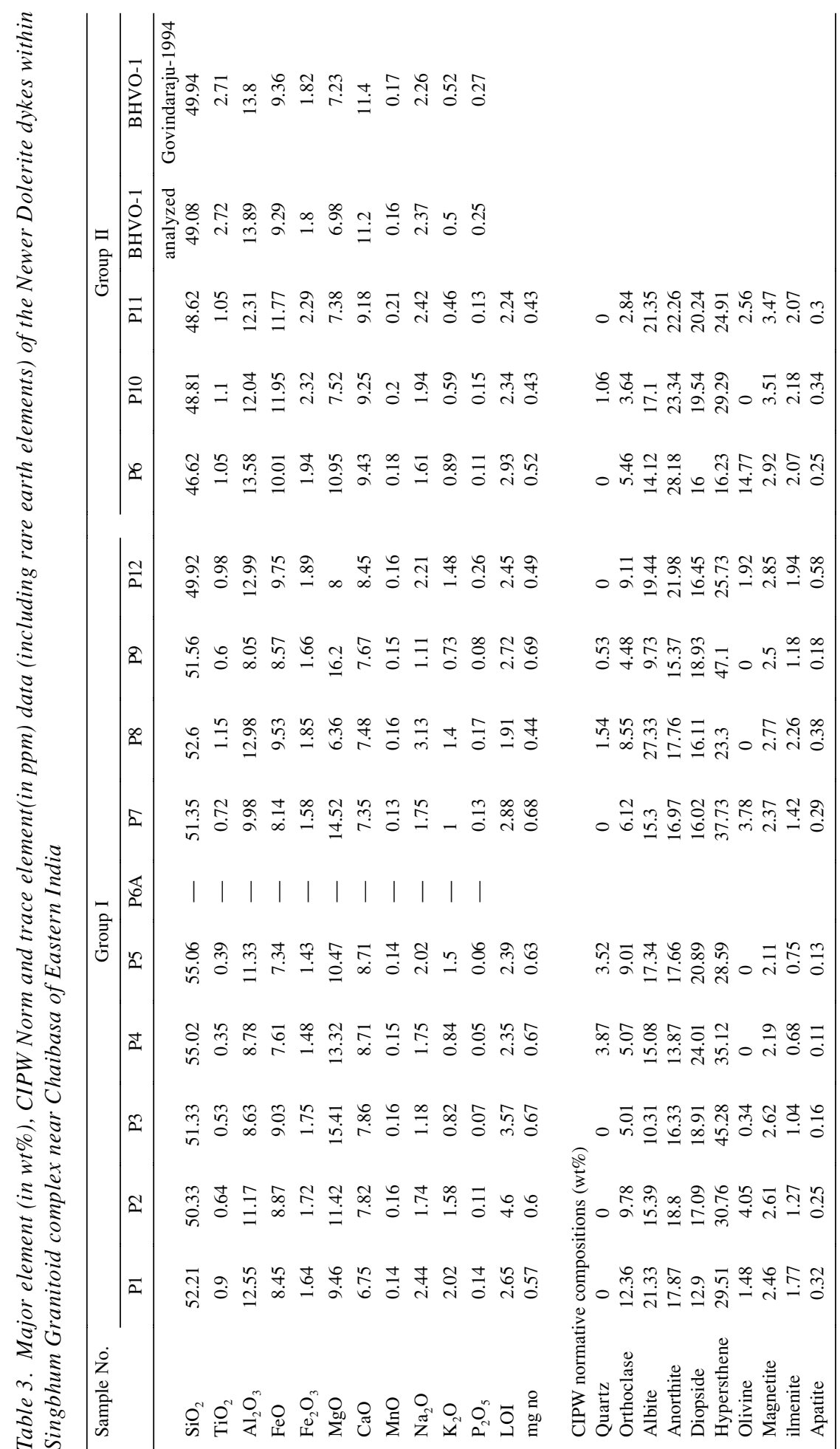




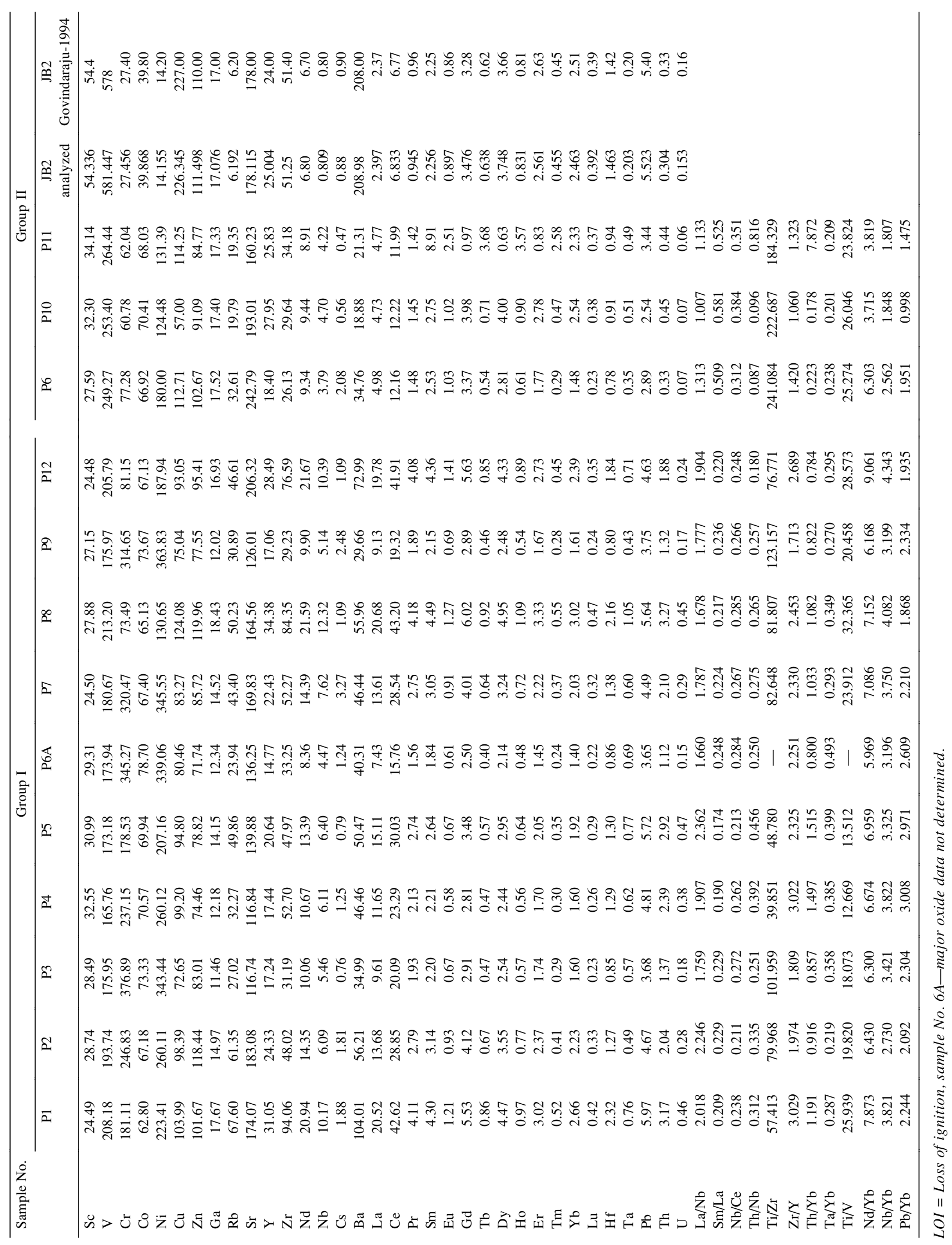




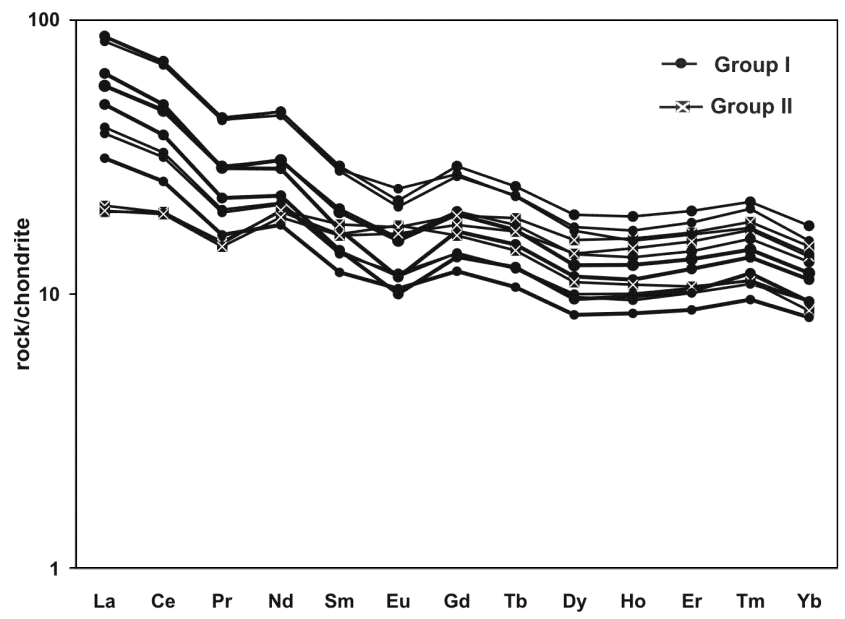

Fig. 5. Chondrite-normalized REE plot (Sun and McDonough, 1989) for the Group I and Group II Newer Dolerite dykes of Chaibasa.

positions. Strong enrichment in LILE (Cs, $\mathrm{Rb}, \mathrm{K}$ and $\mathrm{Sr}$ ) over HFSE ( $\mathrm{Nb}, \mathrm{Zr}$ and Ti), LILE (La, Ce, Pr) enrichment over HREE and prominent negative anomalies of $\mathrm{Nb}, \mathrm{P}$ and Ti suggest arc nature for the Group-I dykes. The multi-element diagram of Group-II dykes (Fig. 6A) is quite similar to E-MORB with enrichment of $\mathrm{K}$ and $\mathrm{Rb}$ and depletion at $\mathrm{Ba}, \mathrm{Zr}$ and $\mathrm{Hf}$, compared to MORB. The negative anomaly of $\mathrm{Zr}$ found in the MORB normalized plot (Fig. 6A) is indicative of the mantle source since $\mathrm{Zr}$ is considered as a relatively immobile element (Floyd and Lee, 1973; Winchester and Floyd, 1977; Macdonald et al., 1988; Mir et al., 2010). The negative Ba anomaly and the relatively lower Ba concentration in both the GroupI and Group-II dykes (29-104 ppm) might indicate lower concentrations of $\mathrm{Ba}$ in the mantle source and also presence of a Ba-depleted subducted pelagic sediments for the mantle source of Group-I dykes (Smith et al., 1986; Roy et al., 2002).

Binary variation diagrams between a few major and trace elements (Fig. 7) clearly demonstrate the existence of two different groups of dykes. In all plots, Group-I dykes show a distinctive trend of evolution in contrast to the Group-II dykes. Trace elements like Nb, La, Ce, Zr are sensitive to variable degrees of partial melting of the mantle or to different sources (Weaver and Tarney, 1981; Ahmad and Tarney, 1991; Petterson and Windley, 1992). A good positive linear correlation $(r=0.9)$ between La$\mathrm{Nb}, \mathrm{Nb}-\mathrm{Ce}, \mathrm{La}-\mathrm{Zr}$ and $\mathrm{Nb}-\mathrm{Zr}$ (Fig. 7) of Group-I dykes suggest variable degree of partial melting of a metasomatized mantle source. Group-II dykes form a cluster in these bivariate diagrams indicating a nearly uniform degree of partial melting of a mantle source similar to MORB.
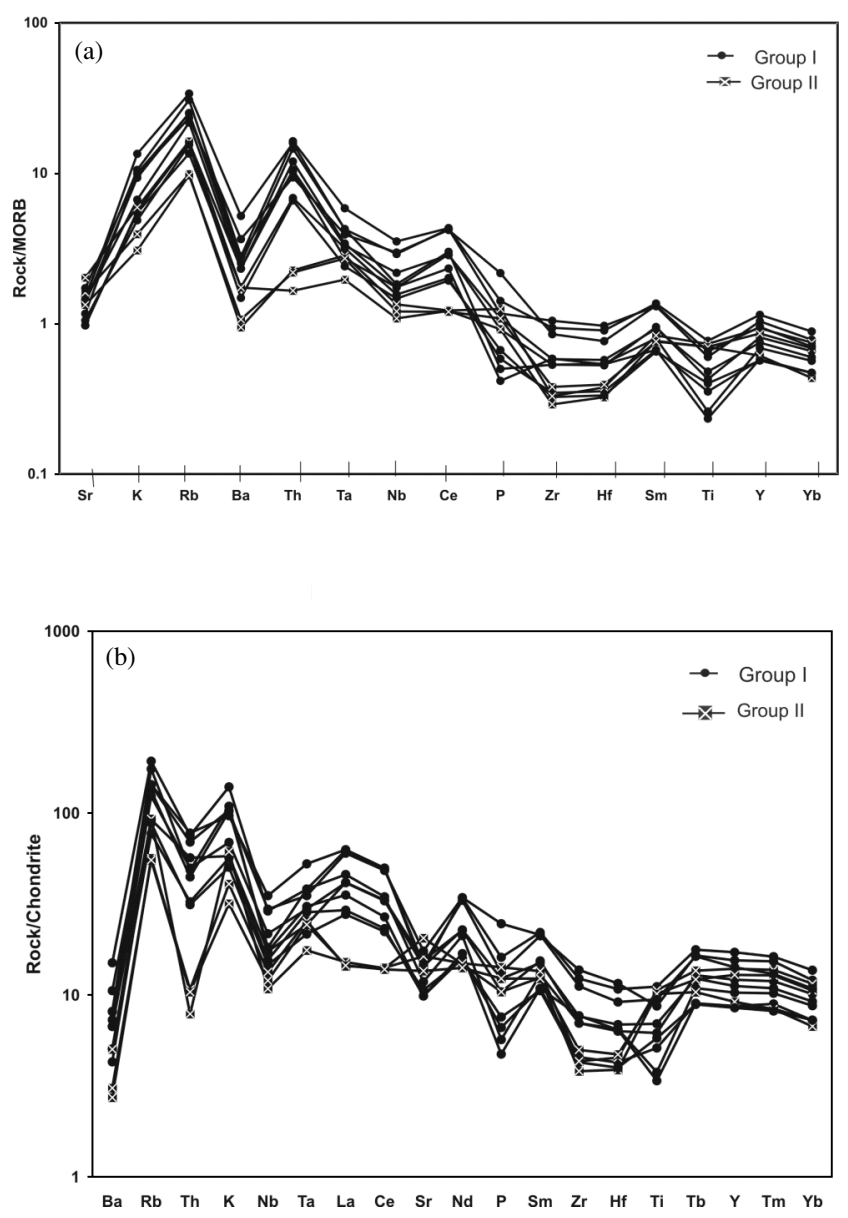

Fig. 6. (A) MORB-normalized (after Pearce 1983) multielement diagram of Group I and Group II Newer Dolerite dykes. (B) Chondrite-normalized (Thompson et al., 1984) multielement diagram for Group I and Group II Newer Dolerite dykes.

\section{REE classification of Group I and Group II dykes}

The significant differences between the chemical nature and tectonic environment of the Group-I and GroupII dykes have been identified with the help of some trace element ratios like $\mathrm{La} / \mathrm{Nb}, \mathrm{Sm} / \mathrm{La}, \mathrm{Nb} / \mathrm{Ce}, \mathrm{Th} / \mathrm{Nb}$ and $\mathrm{Ti} /$ $\mathrm{Zr}$. It has already been established that the Group-I dykes bear signatures of subduction-related tectonic setting. Then it is important to know whether it was an island arc or an active continental margin. For this purpose, a comparative study has been made between Group-I basalts, island arc basalts (IABs) and active continental margin (ACM) basalts on the basis of some trace element ratios as shown in Table 4. This table also contains data of Group-II dykes, E-MORBs (Sun and McDonough, 1989), IABs and ACM basalts (Wilson, 1989).

$\mathrm{La} / \mathrm{Nb}$ ratio of Group-I dykes varies within a wide range from 1.68 to 2.36 and matches well with that of basalts of active continental margin setting (Table 4). This 
a)

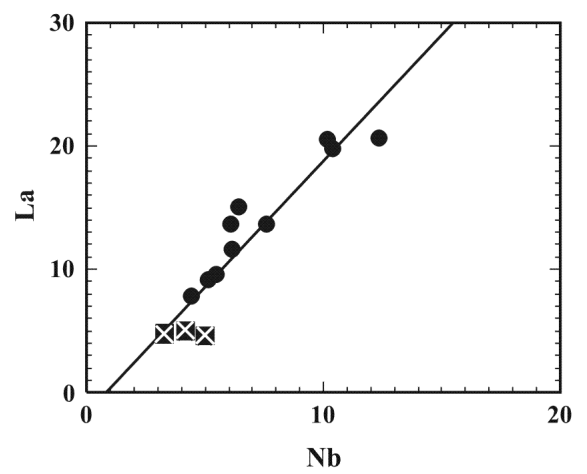

C)

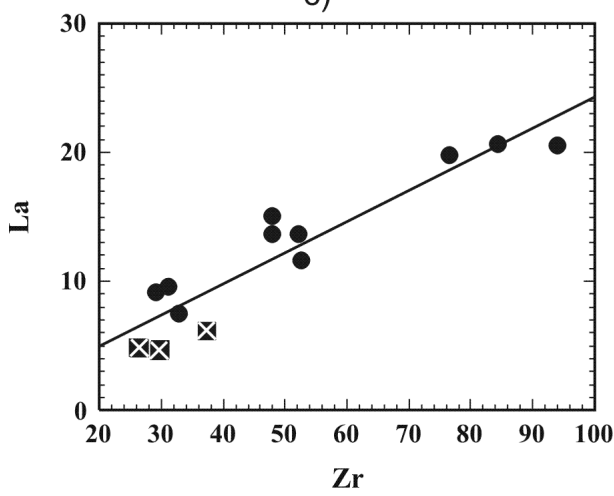

e)

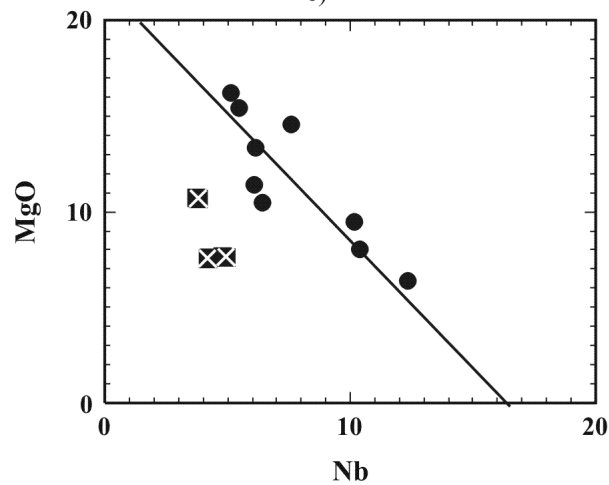

b)

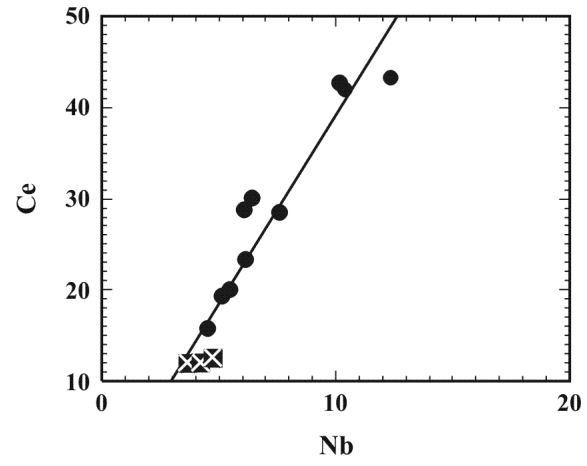

d)

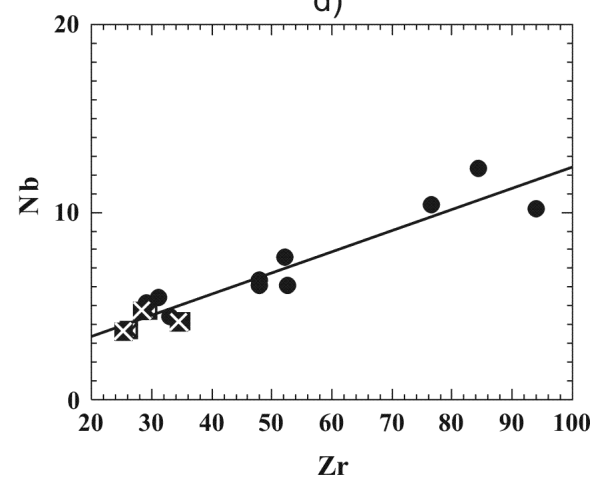

f)

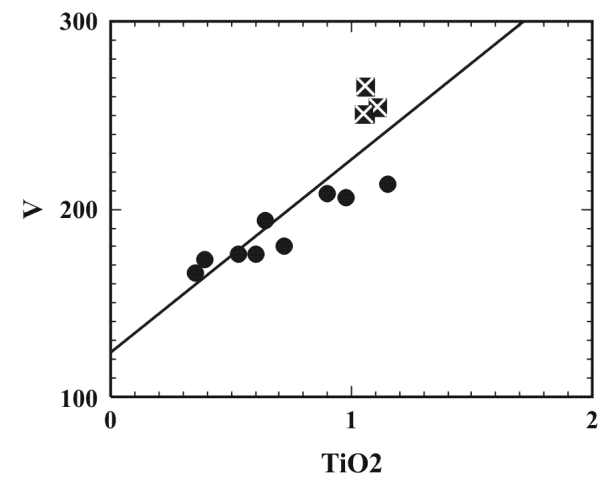

Fig. 7. Binary variation diagrams of (a) La vs. $\mathrm{Nb}$, (b) Ce vs. $\mathrm{Nb}$, (c) La vs. Zr, (d) $\mathrm{Nb} v s . \mathrm{Zr}$, (e) $\mathrm{MgO} v s . \mathrm{Nb}$, (f) $\mathrm{V} v s . \mathrm{TiO}{ }_{2}$.

suggests that the $\mathrm{La} / \mathrm{Nb}$ ratio of mantle source of GroupI dykes are similar to that of the mantle source for basaltic rocks of active continental margin. Sm/La is a useful parameter because it is a measure of the extent of LREE depletion or enrichment. The range of the Sm/La and the $\mathrm{Nb} / \mathrm{Ce}$ ratios (this latter being a useful indicator of mantle metasomatism or contamination) of the Group-II dykes is very close to E-MORB (Sun and McDonough, 1989). The higher $\mathrm{Sm} / \mathrm{La}$ and $\mathrm{Nb} / \mathrm{Ce}$ values of some of the dykes are due to higher $\mathrm{Sm}$ and $\mathrm{Nb}$ concentration relative to $\mathrm{E}$ -
MORB. Both the Sm/La and Nb/Ce of Group-I dykes fall either within or very close to the data range of basalt/ dolerites of active continental margins. High $\mathrm{Th} / \mathrm{Nb}$ ratio of Group-I dykes compared to Group II dykes suggests the involvement of partial melt of subducted sediments (Class et al., 2000; George et al., 2003; Plank, 2005) in Group-I dykes. Although the range of $\mathrm{Th} / \mathrm{Nb}$ ratios of Group-I dykes matches with that of the active continental margin basalts, it also overlaps with that of IABs. This is justified by the fact that melted sediments play an im- 
Table 4. Some important trace element ratios of Group I basalts, Group II basalts, E-MORB, island arc basalts (IABs) and active continental margin (ACM) basalts. Data reference: E-MORBs (Sun and McDonough, 1989), IABs and ACM basalts (Wilson, 1989)

\begin{tabular}{lccccc}
\hline Ratio & Group I & Group II & E-MORBs & IABs & ACM Basalts \\
\hline $\mathrm{La} / \mathrm{Nb}$ & $1.68-2.36$ & $1.01-1.31$ & 1.07 & 1.85 & $1.4-2.3$ \\
$\mathrm{Sm} / \mathrm{La}$ & $0.17-0.23$ & $0.5-0.8$ & 0.4 & 0.9 & $0.19-0.29$ \\
$\mathrm{Nb} / \mathrm{Ce}$ & $0.21-0.29$ & $0.31-0.38$ & 0.31 & 0.189 & $0.21-0.31$ \\
$\mathrm{Th} / \mathrm{Nb}$ & $0.18-0.45$ & $0.08-0.1$ & 0.05 & $0.26-1$ & $0.2-0.5$ \\
$\mathrm{Ti} / \mathrm{Zr}$ & $39-123$ & $184-241$ & 107 & 147 & $48.5-70$ \\
\hline
\end{tabular}

portant role during the genesis of both the IABs and the ACM basalts. The immobile element $\mathrm{Ti} / \mathrm{Zr}$ ratios of Group-I dykes (39-123) are very close to the range (given in Table 4) observed in active continental margin basalts (Wilson, 1989). Some dykes of Group I show higher Ti/ $\mathrm{Zr}$ ratios which are due to a lower $\mathrm{Zr}$ concentration in the source, as discussed earlier (Table 3). The Group-II dykes show a much higher $\mathrm{Ti} / \mathrm{Zr}$ ratio (Table 4) compared to EMORB (Sun and McDonough, 1989) which might be the result of lower $\mathrm{Zr}$ concentration of mantle source of these dykes.

\section{Tectonic setting of the Newer Dolerites}

This study reveals that the Newer dolerite rocks have been affected by hydrothermal alteration under lower greenschist facies metamorphism. This is evident from the common occurrence of albitic plagioclase-chloritetremolite-actinolite assemblages. Clouding in plagioclase feldspar, bastitisation of orthopyroxene, transformation of pyroxene into tremolite-actinolite minerals has been identified as hydrothermal alteration product. In order to avoid problems of element mobility during metamorphism (Pearce, 1996), we are using abundances of relatively immobile trace elements (which remain unchanged during weathering and low grade metamorphism) to derive our inferences on the tectonic setting of these dolerite dykes. The four diagrams Ti vs. V, Cr vs. Y, Zr/Y vs. Zr and $\mathrm{Th} / \mathrm{Yb}$ vs. $\mathrm{Ta} / \mathrm{Yb}$ (Fig. 8) are useful for identifying the tectonic setting of the Newer Dolerite dykes.

The Ti-V diagram of Shervais (1982) is based on variation of partition coefficient of $\mathrm{V}$ under varying oxygen fugacities. In this diagram, all the samples of Group-I dykes plot within the fields of volcanic arc basalts (VAB; $\mathrm{Ti} / \mathrm{V}<20)$ with a few in the MORB field $(\mathrm{Ti} / \mathrm{V}-20$ to 50 ) but the samples of Group-II dykes fall only within the MORB field (Fig. 8). The $\mathrm{Cr}-\mathrm{Y}$ diagram of Pearce (1982) is useful to discriminate arc basalts, MORBs and within-plate basalts (WPBs) since it relies on Y, which is enriched in MORBs and WPBs relative to VABs. Some of the samples of Group-I dykes fall within the field of VAB while some other samples fall in a field which is a common area of arc basalts, MORBs and WPBs. One sam- ple of Group-I falls outside the field of VAB and within a field overlapping MORBs and WPBs. The samples of Group-II plot within the VAB field, two of which are very close to the field of MORBs and WPBs (Fig. 8B). In the $\mathrm{Zr} / \mathrm{Y}$ vs. Zr diagram of Pearce and Norry (1979), the samples of Group-I dykes fall within the fields of arc basalts and MORB (Fig. 8C). The Group-II dykes do not fall within these fields due to their low $\mathrm{Zr} / \mathrm{Y}$ value. The $\mathrm{Th} /$ $\mathrm{Yb}$ vs. $\mathrm{Ta} / \mathrm{Yb}$ diagram of Pearce (1982) can be used to identify the basalts of volcanic arc and their source (Fig. $8 \mathrm{D})$. The preferential enrichment of Th relative to $\mathrm{Ta}$ in subduction-related fluids results in samples that plot above the "mantle array" along a vector nearly parallel to the $\mathrm{Th} / \mathrm{Yb}$ axis. The samples of Group-I dykes plot along such a vertical line indicating their arc nature. Further, the position of Group-I dyke within the field of ACM basalts confirms their continental arc origin. This continental arc origin of Group I dykes has also been identified from trace element ratios like $\mathrm{La} / \mathrm{Nb}, \mathrm{Sm} / \mathrm{La}, \mathrm{Nb} / \mathrm{Ce}, \mathrm{Th} / \mathrm{Nb}, \mathrm{Ti} / \mathrm{Zr}$ (Table 4). The samples of Group-II dykes fall within the mantle array in the MORB field suggesting its mantle source similar to MORB mantle.

\section{Nature of the mantle and its melting}

Generally during subduction, HFSE are not incorporated in the mantle wedge due to their low mobility in fluids (McCulloch and Gamble, 1991; Brenan et al., 1994) and their low concentration in subducting sediments (Plank and Langmuir, 1998). For this reason, abundance of HFSE has often been used to understand the geochemical nature of the mantle wedge prior to subduction. In order to have an estimate about the contribution of the background mantle and the inputs from subduction and contamination processes, we followed the approach of Pearce et al. (1995) for plotting trace element data in diagrams having the form $\mathrm{X} / \mathrm{Yb}$ versus $\mathrm{Nb} / \mathrm{Yb}$, where $\mathrm{X}$ represent both mobile and immobile elements. Both $\mathrm{Nb}$ and $\mathrm{Yb}$ are not mobile in subduction process and their abundances (and their ratio $\mathrm{Nb} / \mathrm{Yb}$ ) remain constant during contamination. The ratio $\mathrm{X} / \mathrm{Yb}$ changes with input of $\mathrm{X}$ from subducted sediment, fluid phase or melt (Pearce, 1983; Pearce and Peate, 1995). 

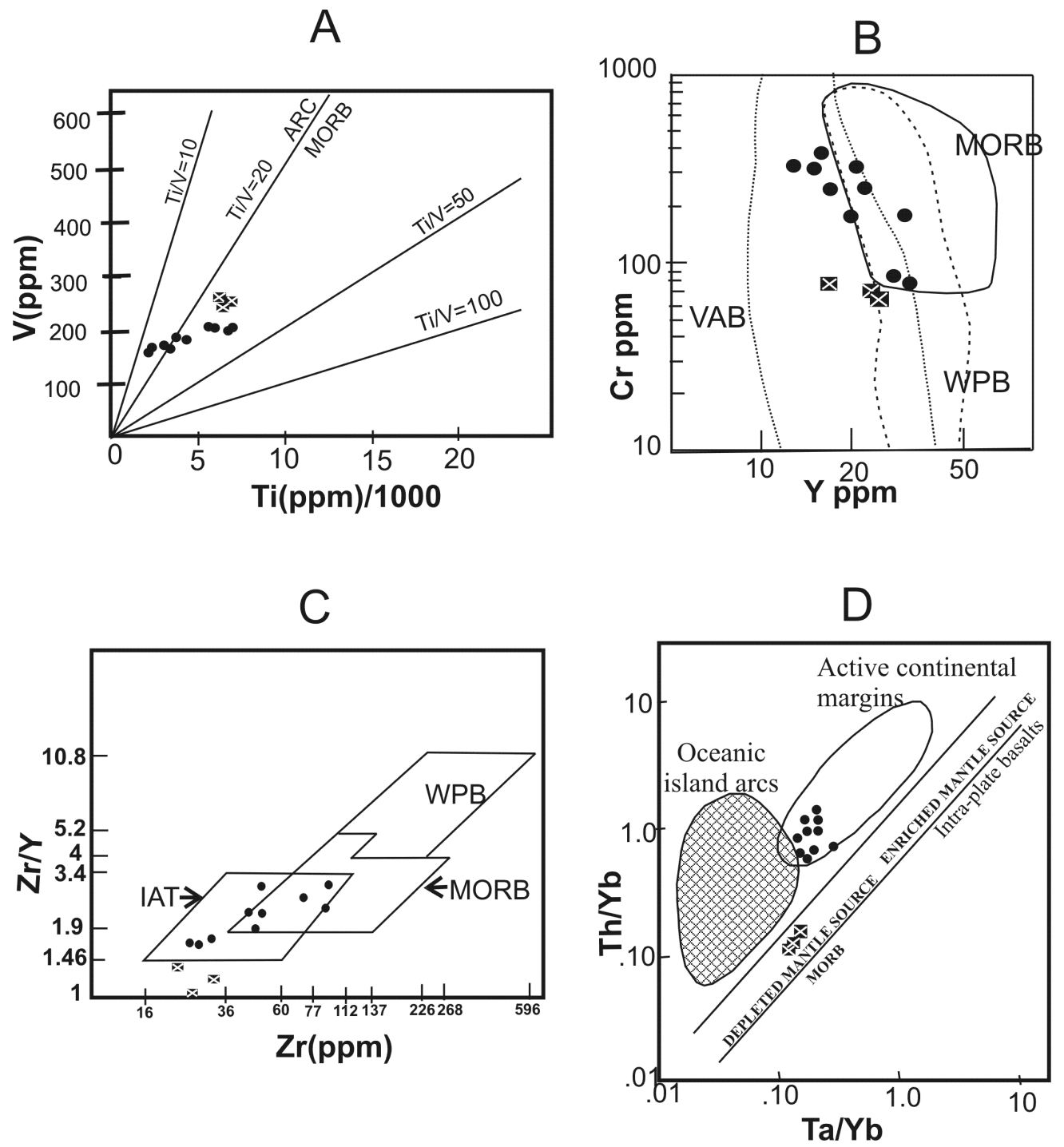

Fig. 8. Tectonic discrimination diagrams. (A) Ti-V diagram of Shervais (1982), Arc-volcanic arc basalt, MORB-Mid-ocean ridge basalt. (B) Cr-Y diagram of Pearce (1982), WPB-within-plate basalt. (C) Zr/Y vs. Zr diagram (after Pearce and Norry, 1979). (D) Th/Yb vs. Ta/Yb plot showing differences between subduction related basalts and oceanic basalts (after Pearce, 1983).

In the plot $\mathrm{Nd} / \mathrm{Yb}$ vs. $\mathrm{Nb} / \mathrm{Yb}$ (Fig. 9), the samples of both the Group-I and Group-II dykes fall within the mantle array along a linear trend though two samples of Group-II are more primitive in nature. This figure indicates that the original mantle source of both the Group-I and Group-II dykes were similar in nature with Group-I dykes showing slightly enriched character. This figure also suggests that Nd did not play any role during the modification of the mantle by subduction/crust/SCLM components.

In the $\mathrm{Zr} / \mathrm{Yb}$ vs. $\mathrm{Nb} / \mathrm{Yb}$ (Fig. 9), the samples of both the Group-I and Group-II dykes form a linear trend along the lower boundary of the mantle array. This feature suggests a low $\mathrm{Zr}$ abundance in the mantle source for both groups of dykes. This $\mathrm{Zr}$ depletion has possibly been attained by extraction of earlier batches of magma from the same source. The depleted geochemistry of N-MORB, which has low $\mathrm{Zr}$ value along with other incompatible elements, has been explained with the same logic (Wilson, 1989). During the metasomatic process the mantle feeding the arc gets enriched with LILE but not with HFSE. Being a HFSE, $\mathrm{Zr}$ is consequently depleted in the residual mantle source. In the present study, dykes of Group-I and Group-II are thought to have been derived from arc mantle and E-MORB mantle respectively, both of these mantle being depleted in $\mathrm{Zr}$ (Misra et al., 1991; Melluso et al., 2003).

In the $\mathrm{Th} / \mathrm{Yb}$ vs. $\mathrm{Nb} / \mathrm{Yb}$ plot (Fig. 9), the Group-I dykes 

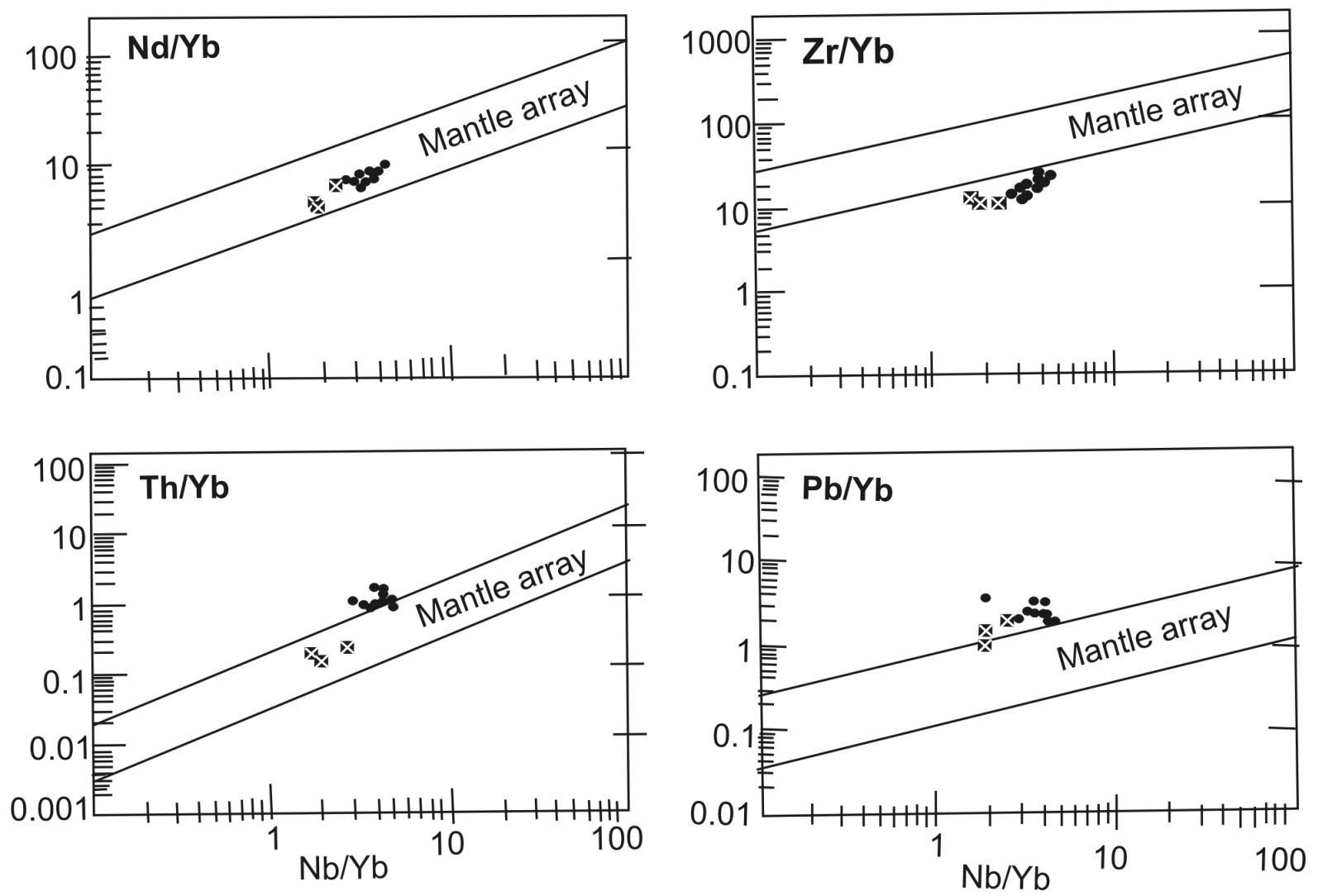

Fig. 9. Plots of $\mathrm{Nd} / \mathrm{Yb}, \mathrm{Zr} / \mathrm{Yb}, \mathrm{Th} / \mathrm{Yb}, \mathrm{Pb} / \mathrm{Yb}$ vs. Nb/Yb for Newer dolerite dykes. Symbols of Group I and Group II dykes are same as previous plots. The Mantle array indicates the range of incompatible element ratios in average MORB and OIB (Green, 2006).

are displaced from the mantle array towards higher $\mathrm{Th} /$ $\mathrm{Yb}$ ratios with a flat slope but the Group-II dykes are still plotted within the mantle array. This plot suggests significant Th contribution from the subduction component to the mantle source of Group-I dykes but not for GroupII dykes.

In the $\mathrm{Pb} / \mathrm{Yb}$ vs. $\mathrm{Nb} / \mathrm{Yb}$ plot (Fig. 9), the Group-I dykes are displaced off the mantle array towards the higher $\mathrm{Pb} /$ $\mathrm{Yb}$ ratio. The Group II-dykes (except for one sample) also plot off the mantle array towards higher $\mathrm{Pb} / \mathrm{Yb}$ ratios. However, the ratio of the Group-I dykes (1.87-3.0) is higher relative to the Group-II dykes (0.95-1.95). As, it has already been established that, Group-II dykes have not been affected by any subduction-related modification, the $\mathrm{Pb}$ enrichment in these rocks suggests effects of crustal contamination.

The overall flat trends of plots of both groups of dykes suggest addition of a subduction component to a metasomatized mantle source. Significant variation in abundances for the REE and good positive correlation among incompatible trace elements of Group-I dykes probably indicate varying degree of partial melting of the source and exclude the possibility of fractional crystalli- zation (Hanson, 1980; Ahmad and Tarney, 1994). Melting was facilitated in the mantle source due to introduction of volatile phases. On the other hand, the unmodified nature of mantle source of Group-II dykes and their compositional similarity with MORB mantle possibly indicate magma generation in the back-arc region where melting was initiated due to decompression. Magmas for both Group-I and Group-II dykes suffered contamination by granitic materials during their migration through crustal conduits (fracture system).

\section{CONCLUSIONS}

Newer Dolerite dykes (Singhbhum Craton, India) include two chemical types-Group I and Group II. GroupI dykes shows LREE fractionated character with respect to chondrite (Sun and McDonough, 1989) and high values of some incompatible element ratios such as $\mathrm{Th} / \mathrm{Nb}$, $\mathrm{Zr} / \mathrm{Y}, \mathrm{Ta} / \mathrm{Yb}$ and $\mathrm{Pb} / \mathrm{Yb}$ (Table 3) indicating their generation from a metasomatized mantle source. Group-II dykes with nearly flat REE pattern and relatively low values of incompatible element ratios such as $\mathrm{Th} / \mathrm{Nb}, \mathrm{Zr} / \mathrm{Y}, \mathrm{Ta} / \mathrm{Yb}$ and $\mathrm{Pb} / \mathrm{Yb}$ (Table 3) likely to have been derived from an 
unmodified mantle source similar to E-MORB. Occurrences of quartz normative tholeiites, quartz-alkali feldspar intergrowth and positive anomalies of $\mathrm{K}$ and $\mathrm{Rb}$ might suggest crustal contamination during migration of the basic magma through crustal conduits. Petrogenesis and geochemical character of these dykes suggest their evolution in a subduction zone tectonic setting-one group (Group I) from a modified (metasomatized) overriding mantle wedge and the other group (Group II) from unmodified mantle in the back arc region.

Acknowledgments-We thank the Department of Science and Technology, New Delhi for providing research grant for the present work. We also thank the Head of the Department of Geology, Presidency University for providing facilities to carry out this work. We would like to thank two anonymous reviewers for their valuable comments and suggestions to modify the text. We are grateful to Dr. Daniele Pinti, the Associate Editor, for his thoughtful and encouraging suggestions which have helped to improve the content and presentation of the revised manuscript.

\section{REFERENCES}

Ahmad, T. and Tarney, J. (1991) Geochemistry and petrogenesis of Garhwal volcanics: implication for evolution of the north Indian lithosphere. Precambrian Res. 50, 69-88.

Ahmad, T. and Tarney, J. (1994) Geochemistry and petrogenesis of late Archean Aravalli volcanics, basement enclaves and granitoids, Rajasthan. Precambrian Res. 65, 1-23.

Armbrustmacher, T. J. and Banks, N. G. (1974) Clouded plagioclase in metadolerite dykes, southeastern Bighorn Mountains, Wyoming. Am. Mineral. 59, 656-665.

Bhattacharyya, D. S. and Sanyal, P. (1988) The Singbhum orogen-its structure and stratigraphy. Precambrian of the Eastern Indian Shield (Mukhopadhyay, D., ed.), Geol. Soc. India Mem. 8, 85-111.

Bleeker, W. (2004) Taking the pulse of planet Earth: a proposal for a new multi-disciplinary flagship project in Canadian solid Earth Sciences. Geosci. Canada 31, 179-190.

Bose, M. K. (1982) Precambrian picritic lavas from Nomira, Keonjhar, eastern India. Curr. Sci. 51, 677-682.

Bose, M. K. (1994) Sedimentation pattern and tectonic evolution of the Proterozoic Singhbhum basin in the eastern Indian shield. Tectonophysics 231, 325-346.

Bose, M. K. (2000) Mafic-ultramafic magmatism in the eastern Indian craton-A review. Geol. Surv. India Spec. Publ. 55, 227-258.

Bose, M. K. (2008) Proterozoic dykes from Singhbhum granite pluton. Indian Dykes (Srivastava, Sivaji and Chalapathi Rao., eds.), Narosa Pub., New Delhi.

Bose, M. K. and Chakraborty, M. K. (1992) Geochemical changes in basalts across the Archean-Proterozoic boundary-an evaluation of Dalma volcanics of Singhbhum crustal province, eastern India. J. Geol. Soc. India 43, 281293.

Bose, M. K., Chakraborti, M. K. and Saunders, A. D. (1989) Geochemistry of the lavas from Proterozoic Dalma volcanic belt, Singhbhum, eastern India. Geol. Rundschau 70, 504518.

Brenan, J. M., Shaw, H. F., Phinney, D. L. and Ryerson, F. J. (1994) Rutile-aqueous fluid partitioning of $\mathrm{Nb}, \mathrm{Ta}, \mathrm{Hf}, \mathrm{Zr}$, $\mathrm{U}$ and $\mathrm{Th}$ : Implications for high field strength element depletions in island-arc basalts. Earth Planet. Sci. Lett. 128, 327-339.

Chakraborty, M. K. and Bose, M. K. (1985) Evaluation of the tectonic setting of Precambrian Dalma volcanic belt eastern India, using trace element data. Precambrian Res. 28, 253-268.

Class, C., Miller, D. M., Goldstein, S. L. and Langmuir, C. H. (2000) Distinguishing melt and fluid subduction components in Umnak Volcanics, Aleutian Arc. Geochem. Geophy. Geosyst. 1, 1999GC000010.

Condie, K. C. (1990) Geochemical characteristics of Precambrian basaltic greenstones. Early Precambrian Basic Magmatism (Hall, R. P. and Hughes, D. J., eds.), 11-39, Chapman and Hall, New York.

Condie, K. C. (2001) Mantle Plumes and Their Record in Earth History. Cambridge University Press, Cambridge, 306 pp.

Deer, W. A., Howie, R. A. and Zussman, J. (1997) An Introduction to the Rock-Forming Minerals. 2nd ed., Prentice Hall, London, $712 \mathrm{pp}$.

Dunn, J. A. (1929) The geology of north Singhbhum including parts of Ranchi and Manbhum districts. Mem. Geol. Surv. India 54, 166.

Dunn, J. A. and Dey, A. K. (1942) Geology and petrology of eastern Singhbhum and surrounding areas. Mem. Geol. Surv. India 69, 261-456.

Ernst, R. E. and Buchan, K. L. (2001) Large mafic magmatic events through time and links to mantle-plume heads. Mantle Plumes: Their Identification through Time (Ernst, R. E. and Buchan, K. L., eds.), Geol. Soc. Am. Spec. Paper 352, 483-575.

Floyd, P. A. and Lees, G. J. (1973) Ti-Zr characterization of some Cornish pillow lavas. Proc. Ussher Soc. 2, 489-494.

George, R., Turner, S., Hawkesworth, C., Morris, J., Nye, C., Ryan, J. and Zheng, S. (2003) Melting processes and fluid and sediment transport rates along the Alaska-Aleutian arc from an integrated U-Th-Ra-Be isotope study. J. Geophys. Res. 108(B5), 2252, doi:10.1029/2002JB001916.

Green, N. L. (2006) Influence of slab thermal structure on basalt source regions and melting conditions: REE and HFSE constraints from the Garibaldi volcanic belt, northern Cascadia subduction system. Lithos 87, 23-49.

Halls, H. C., Palmer, H. C., Bates, M. P. and Phenney, W. C. (1994) Constraints on the nature of the Kapuskasing Structural Zone from the study of Proterozoic dyke swarms. Can. J. Earth Sci. 31, 1182-1196.

Hanski, E. J. and Smolkin, V. F. (1995) Iron- and LREEenriched mantle source for early Proterozoic intraplate magmatism as exemplified by the Pechenga ferropicrites, Kola Peninsula, Russia. Lithos 34, 107-125.

Hanson, G. N. (1980) Rare earth elements in petrogenetic studies of igneous systems. Ann. Rev. Earth Planet. Sci. 8, 371406.

Hoal, K. O. (2003) Samples of Proterozoic iron-enriched mantle from the Premier kimberlite. Lithos 71, 259-272. 
Irvin, T. A. and Baragar, W. R. A. (1971) A guide to chemical classification of common volcanic rocks. Can. J. Earth Sci. 8, 523-548.

Jones, H. C. (1934) The iron ore deposits of Bihar and Orissa. Mem. Geol. Surv. India 63, 167-302.

Kelemen, P. B. (1990) Reaction between ultramafic rock and fractionating basaltic magma I. Phase relations, the origin of calc-alkaline magma series, and the formation of discordant dunite. J. Petrol. 31, 99-134.

Krishnan, M. S. (1936) The dyke rocks of Keonjhar state, Bihar and Orissa. Rec. Geol. Surv. India 71, 105-120.

Le Maitre, R. W. (2002) Igneous Rocks; A Classification and Glossary of Terms. 2nd ed., Cambridge University Press, Cambridge 236 pp.

Macdonald, R., Millward, D., Beddoe-Stephens, B. and Layborn-Parry, J. (1988) The role of tholeiitic magmatism in English lake district: Evidence from dyke in Eskdace. Min. Mag. 52, 459-472.

MacGregor, A. G. (1931) Clouded feldspars and thermal metamorphism. Min. Mag. 22, 524-538.

Mahadevan, T. M. (2002) Geology of Bihar and Jharkhand. Geol. Soc. India, Bangalore, 563 pp.

Mallick, A. K. and Sarkar, A. (1994) Geochronology and geochemistry of mafic dykes from precambrians of Keonjhar, Orissa. Ind Min. 48, 3-24.

Mandal, N., Mitra, A. K., Misra, S. and Chakraborty, C. (2006) is the outcrop topology of dolerite dykes of Precambrian Singhbhum craton fractal? J. Earth Sci. Syst. 115, 643-660.

McCulloch, M. T. and Gamble, J. A. (1991) Geochemical and geodynamical constraints on subduction zone magmatism. Earth Planet. Sci. Lett. 102, 358-374.

Melluso, L., Morra, V., Brotzu, P., Franciosi, L., Petteruti Lieberknecht, A. M. and Bennio, L. (2003) Geochemical provinciality in the Cretaceous basaltic magmatism of Northern Madagascar: mantle source implications. J. Geol. Soc. Lond. 160, 477-488.

Mir, A. R., Alvi, S. H. and Balaram, V. (2010) Geochemistry of mafic dikes in the Singhbhum Orissa craton: implications for subduction-related metasomatism of the mantle beneath the eastern Indian craton. Int. Geol. Rev. 52, 79-94.

Misra, C. K. and Conte, A. J. (1991) Amphibolites of the Ashe and Alligator Back Formations, North Carolina: Samples of Late Proterozoic-early Paleozoic oceanic crust. Bull. Geol. Soc. Am. 103, 737-750.

Mondal, M. E. A. and Ahmad, T. (2001) Bundelkhand mafic dykes, central Indian shield : implication for the role of sediment subduction in Proterozoic crustal evolution. Island Arc 10, 51-67.

Mukhopadhyay, D. (1988) Precambrian of the Eastern Indian Shield-Perspective of the problems. Precambrian of the Eastern Indian Shield. Geol. Soc. India Mem. 8, 1-12.

Murthy, N. G. K. (1995) Proterozoic mafic dykes in Southern Peninsular India. Geol. Soc. India Mem. 33, 81-98.

Naqvi, S. M. (2005) Geology and Evolution of the Indian Plate. Capital Publishing Company, 450 pp.

Pearce, J. A. (1982) Trace element characteristics of lavas from destructive plate boundaries. Andesites (Thorpe, R. S., ed.), 525-548, John Wiley \& Sons.

Pearce, J. A. (1983) Role of the sub-continental lithosphere in magma genesis at active continental margins. Continental Basalts and Mantle Xenoliths (Hawkesworth, C. J. and Norry, M. J., eds.), 230-249, Shiva.

Pearce, J. A. (1996) A user's guide to basalt discrimination diagrams. Application for massive sulphide exploration: Winnipeg. GAC/MAC Short Course Notes (Wyman, D. A., ed.), 12, 79-113.

Pearce, J. A. and Norry, M. J. (1979) Petrogenetic implications of $\mathrm{Ti}, \mathrm{Zr}, \mathrm{Y}$ and $\mathrm{Nb}$ variations in volcanic rocks. Contrib. Mineral. Petrol. 69, 33-47.

Pearce, J. A. and Peate, D. W. (1995) Tectonic implications of the composition of volcanic arc magmas. Annu. Rev. Earth Planet. Sci. Lett. 23, 251-285.

Pearce, J. A., Baker, P. E., Harvey, P. K. and Luff, I. W. (1995) Geochemical evidence for subduction fluxes, mantle melting and fractional crystallization beneath the South Sandwich island arc. J. Petrol. 36, 1073-1109.

Petterson, M. G. and Windley, B. F. (1992) Field relations, geochemistry and petrogenesis of the Cretaceous basaltic Jutal dykes, Kohistan, northern Pakistan. J. Geol. Soc. Lond. 149, 107-114.

Pichamuthu, C. S. (1959) The significance of clouded plagioclase in the basic dykes of Mysore state, India. J. Geol. Soc. India 1, 68-79.

Plank, T. (2005) Constraints from thorium/lanthanum on sediment recycling at subduction zones and the evolution of continents. J. Petrol. 46, 9231-944.

Plank, T. and Langmuir, C. H. (1998) The geochemical composition of subducting sediment and its consequences for the crust and mantle. Chem. Geol. 145, 325-394.

Radhakrishna, T., Krishnendu, N. R. and Balasubramonian, G. (2007) Mafic magmatism around Cuddapah Basin: Age constraints, petrological characteristics and geochemical inference for a possible magma chamber on the South western margin of the basin. J. Geol. Soc. India 70, 194-206.

Robertson, L. M. and Van Breeman, O. (1970) The southern satellite dykes of the Great Dyke, Rhodesia. Geol. Soc. South Africa Spec. Publ. 1, 621-644.

Roy, A., Sarkar, A., Jeyakumar, S., Aggrawal, S. K. and Ebihara, M. (2002) Sm-Nd age and mantle source characteristics of the Dhanjori volcanic rocks, Eastern India. Geochem. J. 36, 503-518.

Saha, A. K. (1948) Kolhan Series-Iron Ore Series boundary to the east and southwest of Chaibasa. Sci. \& Cult. 14, 7779.

Saha, A. K. (1952) On porphyry dykes near Dalsara, Mayurbhanj. Sci. \& Cult. 18, 250-253.

Saha, A. K. (1994) Crustal evolution of Singhbhum-North Orissa, eastern India. Geol. Soc. India. Memo. 27, 341.

Saha, A. K., Bose, M. K., Sankaran, A. V. and Bhattacharyya, T. K. (1972) Petrology and Geochemistry of the ultramafic intrusion of Keshargaria, Singhbhum, Bihar. J. Geol. Soc. India 13, 113-121.

Saha, A. K., Sankaran, A. V. and Bhattacharyya, T. K. (1973) Geochemistry of the Newer dolerite suite of intrusions within the Singhbhum Granite. J. Geol. Soc. India 14, 324346.

Sahu, N. K. and Mukherjee, M. M. (2001) Spinifex textured komatiite from Badampahar-Gorumahisani Schist belt, 
Mayurbhanj Dist., Orissa. J. Geol. Soc. India 57, 529-534. Sarkar, S. N. and Saha, A. K. (1977) The present status of the Precambrian stratigraphy, tectonic and geochronology of Singhbhum-Keonjhar-Mayurbhanj region, eastern India. Ind. J. Earth Sci. S. Ray volume, 37-65.

Sengupta, S., Acharyya, S. K. and Deshmukh, J. B. (1997) Geochemistry of Archean volcanic rocks from Iron Ore Supergroup, Singhbhum eastern India. Proc. Indian Acad. Sci. 106, 327-342.

Shervais, J. W. (1982) Ti-V plots and the petrogenesis of modern and ophiolitic lavas. Earth Planet. Sci. Lett. 59, 101118.

Sinha-Roy, S. and Gupta, K. R. (1995) Continental crust of Northwestern and Central India. Geol. Soc. India Mem. 31, 544.

Smith, T. E. (1992) Volcanic rocks of early Proterozoic greenstone belts. Proterozoic Crustal Evolution (Condie, K. C., ed.), Develop. Precambrian Geol. 10, 7-54, Elsevier.

Smith, T. E., Thirwall, M. F. and Macpherson, C. (1986) Trace element and isotope geochemistry of volcanic rocks of Bequia, Grenadine islands, Lesser Antilles arc: a study of subduction enrichment and intra-crustal contamination. $J$. Petrol. 37, 117-143.

Srivastava, R. K. (2006) Precambrian mafic dyke swarms from the Central Indian Bastar craton: temporal evolution of the subcontinental mantle. Dyke Swarms-Time Markers of Crustal Evolution (Hanski, E., Mertanen, S., Ramo, T. and Vuollo, J., eds.), 147-159, Taylor \& Francis Group, Lon- don.

Subba Rao, D. V., Balaram, V., Charan, S. N., Sridhar, D. N. and Naqvi, S. M. (2004) Proterozoic mafic dykes in and around Chattisgarh basin, central India: inferences of compositional variation in mantle sources. DST-DCS News Lett. 14, 1-5.

Sun, S. S. and McDonough, W. F. (1989) Chemical and isotopic systematics of oceanic basalts: implication for mantle composition and processes. Geol. Soc. Spec. Publ. 42, 313-345.

Thompson, R. N., Morrison, M. A., Henry, G. L. and Parry, J. (1984) An assessment of the relative role of crust and mantle in magma genesis. Phil. Trans. R. Soc. Lond. A310, 549590 .

Thurston, P. C. (1990) Early Precambrian basic rocks of the Canadian shield. Early Precambrian Basic Magmatism (Hall, R. P. and Hughes, D. J., eds.), 221-247, Chapman and Hall, New York.

Weaver, B. L. and Tarney, J. (1981) The Scourie dyke suite: Petrogenesis and geochemical nature of the Proterozoic subcontinental margin. Contrib. Mineral. Petrol. 78, 175188.

Wilson, M. (1989) Igneous Petrogenesis. Unwin Hyman, London, $466 \mathrm{pp}$.

Winchester, J. A. and Floyd, P. A. (1977) Geochemical discrimination of different magma series and their differentiation products using immobile elements. Chem. Geol. 20, 325344. 